\title{
Antiplasmodial Effect of a Crude Extract of the Leaves of Xylopia Parviflora (Benth) On Plasmodium Yoelli Infection in Mice Fed Supplemented Dietary Pellets
}

\author{
B.B. Bukar* ${ }^{1}$ M.O Uguru ${ }^{1}$ D.W. Dayom ${ }^{2}$ \\ Department of Pharmacology. University of Jos, Nigeria \\ Department of clinical Pharmacy, university of Jos, Nigeria
}

\begin{abstract}
The antiplasmodial activity of the leaves of Xylopia parviflora (Benth, L, FAM: Annonaceae) was evaluated in dietary-controlled mice models. Mice were fed on pellets containing varying nutrient constituents for 21 days and thereafter inoculated with Plasmodium yoelii parasites.

Results obtained showed that mice fed with normal pellets responded to treatment with chloroquine $5 \mathrm{mg} / \mathrm{kg}$ and extract 100 and $200 \mathrm{mg} / \mathrm{kg}$ of body weight with suppression of $90.52,70.23$ and $86.90 \%$ respectively as compared to those fed on protein-deficient and palm oil-supplemented pellets. There was significant decrease in mean parasitized erythrocytes count in mice that were fed with normal food pellets compared to that of control $96 \mathrm{hrs}$ after treatment with chloroquine, $5 \mathrm{mg} / \mathrm{kg}$ and extract $200 \mathrm{mg} / \mathrm{kg}(P<0.05)$. However, mice that fed on palm oil supplemented and protein deficient pellets had mean erythrocytes count that was not significantly different from that of control 96hrs after treatment with the extract at both doses $(P>0.05)$ but significant in those that received chloroquine treatment $(P<0.05)$.Parasitaemia was highest in mice that were fed with protein-deficient pellets $72 \mathrm{hrs}$ after inoculation. After stopping treatment, all mice treated with chloroqune in all groups survived 28 days. A similar observation was made with the extract at $200 \mathrm{mg} / \mathrm{kg}$, except in mice fed protein deficient pellets where survival dropped to 60\%. Based on these observations, we submit that that the extract of Xylopia parviflora may possess some antiplasmodial activities. We also suggest the need for increase protein supplementations and restriction of palm oil intake for effective pharmacological interventions in malaria therapy.
\end{abstract}

Keywords: Antiplasmodial activity, Medicinal plants, Nutritional status Plasmodium Yoelli, Xylopia Parviflora.

\section{Introduction}

Malaria, an infectious parasitic disease is perhaps as old as the history of mankind. It has remained a medical as well as a public and economic problem especially in areas where it is endemic. It has been reported to be the cause of most debility and deaths for millions of people particularly in tropical regions of the world [1, 2,3]. According to a 1993 report of World Health Organization (WHO), the clinical incidences of malaria are constantly high [4]. Indeed, past and present statistics on malarial cases have revealed its worsening problems especially in tropical Africa. This is more frightening in the face of the resurgence of malarial parasite resistance to most existing antimalarials couple with wrong perceptions and attitudes to the disease [5, 6].Indeed, according to the World Malaria Report released by WHO for 2012,malaria still remains one of the world's leading infectious killer. It was observed that the fight against malaria in tropical Africa remains unimpressive in spite of concerted efforts by the endemic countries in conjunction with donor agents to strengthen control of the disease [7].

Of importance in malaria and indeed other parasitic diseases is the nutritional factor. Diets of host are said to influence the growth and development of the malarial parasites which has been observed to influence the outcome of antimalarial therapy. [8]. However, this observation appears contentious $[9,10]$. Nonetheless; it is a common knowledge that dietary restrictions during malarial infections are sometimes observed. However, whether such restrictions are to speed up recovery or prevent the parasites from multiplying remains unresolved.

The use of medicinal plants to treat febrile condition is common practice and some of such plants have shown promising antimalarial activity [11]. Indeed most of the existing antimalarials are plant products with artemisinin from Artemisia аппиа L (FAM. Asteracae), being the most recent. Xylopia parvilora (Benth) is traditionally claimed to be effective in the treatment of malaria and spp of this family have been documented among others but not investigated [12,13]. It grows freely in mountainous regions of Nigeria and other West African countries [14]. It has been reported as having no significant toxicity and also found to possess some antipyretic/analgesic properties $[15,16]$. Phytochemical screening of the plant revealed the presence of isoquinoline alkaloids $[17,18]$. The present study is to evaluate its antiplasmodial effect in dietary controlled mice models. 


\subsection{Experimental Animals}

\section{Materials And Methods}

Albino Swiss mice of both sexes weighing between 28-32 g were obtained from the Animal House Unit of the University of Jos. They were kept separate and allowed free access to normal feed until the commencement of the experiment.

\subsection{Collection of Plant}

The leaves of Xylopia parviflora were collected in Babale, a suburb of Jos in Jos North LGA, Plateau State, by a herbalist, Mrs. Azamya Sule in the month of August, 2006. The leaves were identified and authenticated by Mr. Karim of the Federal School of Forestry, Jos and a voucher specimen was prepared and deposited in their herbarium.

\subsection{Preparation of Extract}

The leaves were washed, dried under the shade and powdered, $1000 \mathrm{~g}$ of the powdered material was weighed and soaked in $250 \mathrm{ml}$ of distilled water and extraction was carried out cautiously in a Soxhlet extractor for $72 \mathrm{hrs}$. The extract was evaporated to dryness and the yield was calculated and found to be $8.93 \%$ of dry weight of sample. The extract was preserved at $-5^{\circ} \mathrm{C}$ in a refrigerator until the beginning of the experiments.

\subsection{Acute Toxicity Test (LD (50 $_{0}$ Determination)}

The acute Toxicity test was carried to determine the $\mathrm{LD}_{50}$ of the crude extract. The graphical method of Miller and Tainter [19] was used.

\subsection{Evaluation of Antiplasmodial Activity of $P$. yoelli Parasites}

$P$. yoelii parasites were obtained from the National Institute of Pharmaceutical Research and Development (NIPRD), Abuja, FCT, by passaging in mice. They were maintained by continuous passage until the experiment.

\subsection{DIETARY MANIPULATION}

The mice were randomly divided into three major groups of 20 mice each. The first group were fed with normal diets daily for 21 days (Table 1). The second group were fed with red palm oil-supplemented diet $(6.5 \% \mathrm{~V} / \mathrm{w})$ daily ad libitum for 21 days and the third group were fed with protein deficient diets $(3 \% \mathrm{~W} / \mathrm{w})$ daily for the same period. Animals in each group were further subdivided into four groups of five animals each and their baseline mean erythrocyte counts were determined using the method described by Nelson and Morris [20].

\subsection{DETERMINATION OF ANTIPLASMODIAL ACTIVITY}

The 4-day test (Rane test) as described by Knights and Peters [21] was used. The mice were inoculated with infected blood from previously infected mice collected by cardiac puncture and diluted with physiological saline. The animal were injected intraperitonealy with $0.2 \mathrm{ml}$ of the infected blood containing about $1 \times 10^{7}$ parasitized erythrocytes, on day 3 after inoculation thin blood films were made from the tail of each mouse, fixed with methanol, stained with Giemsa stain and examined for parasitaemia level under the microscope at x100 magnification. Thereafter, normal saline, $1 \mathrm{ml} / \mathrm{kg}$, was orally administered daily to mice in control groups for 4 days. Mice in groups 2 of each dietary group were administered Chloroquine $5 \mathrm{mg} / \mathrm{kg}$ orally while those in groups 3 and 4 received the extract at doses of 100 and $200 \mathrm{mg} / \mathrm{kg}$ daily by oral route for 4 days respectively. On the $4^{\text {th }}$ day of treatment, parasitaemia levels for each mouse were determined using the method described above and the suppression of parasitaemia in each group by the drug are extract was calculated using the

Expression: $\%$ suppression $=\%$ parasitaemia in control $-\%$ parasitaemia in treated group

\subsection{Statistical Analysis.}

$$
\% \text { parasitaemia in control }
$$

Parasitaemia and erythrocytes counts were analysed statistically by analysis of variance (ANOVA) and by student's t-test. Differences of $\mathrm{P}<0.05$ were regarded as statistically significant.

\section{Results}

The LD50 of the crude extract (oral) was found to be $1,680 \mathrm{mg} / \mathrm{kg}$. The effect of Xylopia parviflora leave extract on Plasmodium yoelii progression in dietary controlled mice models are presented on tables 1,2 and 3 and also in Figure 1.

The results revealed that the extract possesses a dose-dependent antiplasmodial activity especially in infected mice fed with normal pellets. However, the antiplasmodial effect was not significant $(\mathrm{P}>0.05)$ at a dose of $100 \mathrm{mg} / \mathrm{kg}$ compared to control. The antiplasmodial effect of the extract in mice fed on palm oil-supplemented pellets $(6.5 \%)$ was similar to those fed on protein-deficient pellets. Parasitaemia levels $72 \mathrm{hrs}$ after infection were 
highest and significant in mice fed on protein-deficient pellets and lowest in those fed on normal pellets $(\mathrm{P}<0.05)$. Suppression of parasitaemia was highest and significant with chloroquine $5 \mathrm{mg} / \mathrm{kg}$ in all groups and in general highest in groups that fed on normal pellets $(\mathrm{p}<0.05)$. 28-days after stoppage of treatment, all mice that received chloroquine $5 \mathrm{mg} / \mathrm{Kg}$ in all groups survived $(100 \%)$. A similar observation was made in mice treated with the extract $200 \mathrm{mg} / \mathrm{kg}$, except those fed on protein-deficient pellets where survival dropped to $60 \%$. Animals left untreated all died ( $0 \%$ survival) in all groups 28 days after stoppage of treatment. (Tables $2 \& 3$, Fig: $1 \& 2)$

\section{Discussions}

The antiplasmodial effect of the crude extract of $X$ parvifora leaves was evaluated in mice models fed pellets of different nutritional contents and infected with $P$. yoelii.

Three days after inoculation with parasites, parasitaema levels in mice fed with palm oil supplemented and protein-deficient pellets were significantly higher compared to those that were fed with normal pellets $(\mathrm{P}<$ 0.05). This probably supports other observation that anti-oxidant nutrients such as vitamin E contained in red palm oil as well as protein deficient-diets (kwashiorkor) favour the growth and survival of the malarial parasites $[22,23]$. Indeed protein energy malnutrition is said to be associated with greater malarial morbidity and mortality [24]. Nonetheless, the influence of red palm oil and other tropical cooking oils on the survival and growth of malarial parasites has been of concern but remains contentious [10].A possible mechanism of the role of red palm oil on malarial infection have recently been suggested by Yahya and Kadir [25]. Palm oil contains vitamin E mainly as tocopherol and tocotrienol and these serve as anti-oxidants against oxidative stress. Studies concerning the protective effect of vitamin E deficiency against malaria and those targeted at imposition of oxidative stress based on the sensitivity of the malarial parasites to oxygen have revealed the need to moderate the intake of diet with high content of vitamin $\mathrm{E}$ and other nutrients including iron [26, 27].

However, the suppressive effect of the extract decreased to 46.68 and $65.74 \%$ respectively in animals fed red palm oil and to 53.35 and $63.57 \%$ respectively in those fed protein-deficient pellets. The suppressive effect of chloroquine also decreased from $90.52 \%$ in control group to 78.31 and $78.24 \%$ in groups fed palm oil supplemented and protein deficient pellets respectively. In spite of these, it was found that the antiplasmodial effect of the crude extract remained significant at $200 \mathrm{mg} / \mathrm{Kg}(\mathrm{P}<0.05)$. Reports have shown that dietary restriction is an aspect of human population adaptation to malaria and other infectious diseases [26]. Indeed depressed vitamin E levels have been suggested to have a beneficial effect on the course of malarial infection. Green [28] suggested that dietary adaptation of traditional cuisines in human population living in areas where malaria is endemic augments the oxidative stress on parasitized erythrocytes. Susceptibility to oxidative stress is a well established feature of the malarial parasites especially the asexual forms [22]. This has been exploited in drug design leading to the discovery of anti-malarias such as qinghaosu, which acts by the imposition of oxidative stress by generating free radicals $[30,31]$.

The decreased suppressive effect of both chloroquine and the crude extract in mice fed with red palm oil or protein deficient-pellets though not significant, may suggests that the extract like chloroquine perhaps does not impose oxidative stress on the malarial parasites. Chloroquine is believed to act by inhibiting hem polymerase, an enzyme that the plasmodium parasite uses to polymerize and detoxifies hem liberated during digestion of the host hemoglobin [32]. This would perhaps suggest that the use of chloroquine in infected individuals feeding on palm-oil supplemented diets though effective, be used with moderation to prevent the emergence of resistant strains.

It was observed that parasitaemia was highest in mice fed on Protein-deficient pellets followed by those fed on palm oil-supplemented pellets. These were significant compared to those fed on normal pellets $(\mathrm{p}<0.05)$. This perhaps suggests that malnutrition indeed aggravates malaria and underscores the need to always reduce or restrict intake of palm oil and other antioxidants in individuals having malarial infection. During such periods affected individuals would rely on the cellular anti-oxidant defense mechanisms of the red blood cells through the glutathione pathway $[33,34]$.

\section{Conclusion}

In conclusion we submit that the crude extract of Xylopia parviflora, possesses some antiplasmodial activities that could be beneficial in the treatment of malaria. Also if this finding from animal models can be applied to human malaria, we then suggest the need for increase dietary protein supplementation as well as restriction or reduction of palm oil intake by individuals diagnosed with the disease in order to achieve effective pharmacological interventions in malaria therapy. 


\section{Acknowledgement}

We are greatly indebted to Miss. Victoria Otunyo and Mr. Olufunsho Samuel for their technical assistance. We are also indebted to Messr. Ameh and Solomon of Animal House Unit, University of Jos for taking care of the animals used in this experiment.

\section{References}

[1]. Bradley D.J., Malaria: Old Infection, Changing epidemiologist. Health Trans. Rev.2 (suppl), 1992, $137-153$.

[2]. World Health Organization.Mental Health:New understanding,new hope.World Health Report,Geneva,WHO 2001.

[3]. Fisher P.R. and Bialek R., Prevention of malaria in children.Clin.Inf.Dis.34:2002, 493-498

[4]. World Health Organization, Malaria: Progress in tropical disease research .WHO, Geneva, 1993, 15-27.

[5]. Vundule C. and Mharakurwa S., Knowledge, practice and perceptions about malaria in rural communities of Zimbabwe: relevance to malaria control.WHO. Bull. 74:1996, 55-60.

[6]. Bukar B.B., Uguru M.O., Dayom D.W., Gyang S.S. and Audu-Peter J.D, Preliminary evaluation of Antinociceptive and antipyretic activities of aqueous extract of the leaves of Xylopla Parviflora. J.Pharm. Biores. 2, 2006, 43-48.

[7]. World Health Organization, World Malaria Report 2012, WHO Publication,Geneva,2012

[8]. Levendar O.A. Ager A.L., Morris V.C. and May R.G., Qinghaosu, dietary Vitamin E, Selenium and Cod liver oil: effect on the Susceptibility of Mice to the malarial parasite, Plasmodium yoelii Am. J. Clin. Nutr 50: 1989, 346-352.

[9]. Nesheim M.C., Human nutrition needs and Parasitic Infections. Parasitology 107, 1993, S7-S18.

[10]. Cooper K.A., Adelakan D.A., Esimai A.O., Northrop-clewed C.A., Thurmham D.L., Lack of influence of Red Palm oil on severity of malaria infection in Pre-school Nigerian Children.Trans.R.Soc.Trop.Hyg.96, 2002, 216-223

[11]. Krettli A.U., Andrade-Neto V.F., Branda M.G.L. and Ferrani W.M.S., The Search for new Anti-malarial drugs from plants used to treat fever and malaria: A review. Mem. Inst. Oswaldo. Cruz 96: 2001, 1033-1042.

[12]. Titanji V.P.K., Zofou D.and Ngemenya M.N.,The antimalarial potential of medicinal plants used for the treatment of malaria in Camerounian folk medicine.Afr.J.Trad.CAM.5(3):2008,302-321

[13]. Tsabang N., Foskou P.V., Tchokouaha L.R.Y., Noguem B., Bakaruga-Via I., Nguepi M.S.D., Nkongmeneck B.A.and Boyoma F.F., Ethnopharmacological survey of Annonaceae medicinal plants used to treat malaria in four areas of Cameroun.J.Ethnopharm.139(1):2012,171-180

[14]. $\quad$ Burkill, H.M., The useful Plants of West Africa. Vol 2, pp 457, 1985

[15]. Bukar B.B, Uguru M.O, Edache, P.J. Wannang N.N and Dayom D.W.,Sub-Chronic toxicity evaluation of the aqueous extract of the leaves of Xylopia parviflora in Rats.Nig.J.Pharml.Res.4, 2005, 55-59

[16]. Nishiyama Y., Moriyasu M., Ichimaru M., Iwasu K., Kato A., Mathenge S.G., Mutiso P.B.C.and Juma F.D., Antinociceptive effect of the extract of Xylopia parviflora bark and its alkaloid compounds in experimental animals.J.Nat.Med.64(1):2010,9-15

[17]. Nishiyama Y., Moriyasu M., Ichimaru M., Iwasa K., Kato A., Mathenge S.G., Mutiso P.B.C. and Juma F.D., Quartenary Isoquinoline alkaloids from Xylopia Parviflora. Phytochem. 65: 2004, 939-944.

[18]. Nishiyima Y., Moriyasu M., Ichimaru M., Iwasa K., Kato A., Mathenge S.G., Mutiso P.B.C.and Juma F.D., Secondary and tertiary alkaloids from Xylopia parviflora.Phytochemistry, 67(24):2006,2671-2675

[19]. Miller L.C. and Tainter M.L., Estimation of ED50 Error by means of log-graph paper. Proc. Soc. Exp. Biol. Med. 57: 1944, 261269.

[20]. Nelson D.A. and Morris M.W., Basic Examination of blood. In, Henry JB (Ed). Clinical diagnosis and management by laboratory methods $18^{\text {th }}$ Ed Philadelphia: WB Sanders. 1991 553-603.

[21]. Knight D.J. and Peters W., The anti-malarial activity of N-benzyloxy dihydrotriazines. The action of Clociguanil against rodent malaria and studies on its mode of action. Ann Trop. Med Parasitol. 74:1981, 393-404.

[22]. Levendar O.A. and Ager A.L., Malarial Parasites and Antioxidant Nutrients. Parasitology 107: 1993, 595-5106.

[23]. Hunt N.H., Mandia N., Thumwood C.M., Amelioration of Murine cerebral Malaria by dietary restriction.Parasitology 107, 1993, 471-476.

[24]. Shankar A.H., Nutritional modulation of malaria mobility and mortality. The J. Infectious Diseases182: 2000, 537-553.

[25]. Yahya M.F.R. and Kadir R.A.,Palm oil supplementation prevents further tyrosine phosphorylation of erythrocytes 30-KDA during Plasmodium berghei infection.Int.J.Pharm.Biol.Sci.(IJPBS) 3:2013,131-137

[26]. Murray M.J. and Murray A.B., Starvation Suppression and re-feeding activation of infection: an ecological necessity. Lancet 1: 1977, 123-125.

[27]. Golenser J. and Chevion M., Implications of Oxidant Stress and Malaria: A review. In. tropical Medical, Implication of Oxygen free radical (Arouna O.I (Ed). Hoden Herwood Academic Publisher, 1993, 53-79.

[28]. Green L.S., Genetic and dietary adaptation to malaria in human Populations. Parasitology 41, 1999, $185-192$

[29]. Klayman D.L., Qinghaosu(artemesinin):an anti-malarial drug from China.Science.228:1985,1049-1053

[30]. Meshnick S.R., Thomas A., Ranz A., Xu C.M.and Pan H.Z., Artemisinin(Qinghaosu):the role of intracellular hemin in its mechanism of anti-malarial action.Mol.Biochem.Parasitol., 49:1991,181-190

[31]. Slater A.F.G. and Carami A., Inhibition by Chloroquine of a novel heam polymerase enzyme activity in malaria trophozoites Nature $355,1992,167-169$

[32]. Eaton J.W., Eckman T.R., Berger E. and Jacob H.S., Suppression of Malarial Infection by Oxidant Sensitive host erythrocytes. Nature 264, 1976, 758-760.

[33]. Friedman M.J., Oxidant damage Mediates Variant RBC resistance to Malaria. Nature 280, 1979, $245-234$.

[34]. Eckman J.R., Eaton J.W., Berger E. and Jacob H.S., Role of Vitamin E in regulating malarial expression. Trans.Asso.Am.Physicians 89, 1977 105-115. 
TABLE 1: COMPOSITION OF A NORMAL DIETARY PELLET

\begin{tabular}{|l|l|l|}
\hline Ingredient & Qty $\mathrm{mg} / \mathrm{kg}$ & $\%$ \\
\hline Maize (Red) & 100 & 20 \\
\hline Maize offal & 200 & 40 \\
\hline Fish meal & 50 & 10 \\
\hline Soya beans & 50 & 10 \\
\hline Groundnut cake & 50 & 10 \\
\hline Rice brand & 45 & 9 \\
\hline Methionine & 0.5 & 0.1 \\
\hline Lysine & 0.5 & 0.1 \\
\hline Premix & 2.5 & 0.5 \\
\hline Salt & 1.5 & 0.3 \\
\hline
\end{tabular}

TABLE 2: ANTIPLASMODIAL ACTIVITY OF XYLOPIA PARVIFLORA EXTRACT DURING EARLY P. YOELII INFECTION IN MICE FED ON NORMAL PELLETS

\begin{tabular}{|c|c|c|c|c|c|c|c|c|}
\hline $\begin{array}{l}\mathrm{G} \\
\mathrm{P}\end{array}$ & $\begin{array}{l}\text { TREATME } \\
\text { NT }\end{array}$ & 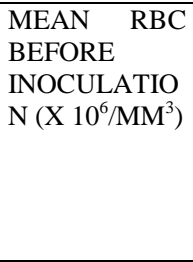 & $\begin{array}{l}\text { MEAN } \\
\text { PARASITISE } \\
\text { D RBC } 72 \\
\text { HRS AFTER } \\
\text { INOCULATI } \\
\text { ON } \quad(\mathrm{X} \\
\left.10^{6} / \mathrm{MM}^{3}\right)\end{array}$ & $\begin{array}{l}\% \\
\text { PARASIT } \\
\text { AEMIA } \\
72 \mathrm{hrs} \\
\text { AFTER } \\
\text { INOCULA } \\
\text { TION }\end{array}$ & $\begin{array}{l}\text { MEAN } \\
\text { PARASITIZED } \\
\text { RBC AFTER } 96 \\
\text { hrs OF } \\
\text { TREATMENT } \\
\text { X106/.MM }\end{array}$ & $\begin{array}{l}\% \\
\text { PARASI } \\
\text { TAEMIA } \\
\text { AFTER } \\
96 \mathrm{hrs} \\
\text { OF } \\
\text { TREAT } \\
\text { MENT }\end{array}$ & $\begin{array}{l}\% \\
\text { SUPPRE } \\
\text { SSION }\end{array}$ & $\begin{array}{l}28- \\
\text { DAY } \\
\text { SURV } \\
\text { IVAL }\end{array}$ \\
\hline I & $\begin{array}{l}\text { NORMAL } \\
\text { pellets+ } \\
\text { NORMAL } \\
\text { SALI }\end{array}$ & $4.7425 \pm 1.63$ & $0.6558 \pm 0.18$ & 13.83 & $0.930 \pm 0.29 * *$ & 19.62 & - & $0 / 5$ \\
\hline II & $\begin{array}{l}\text { Normal feed } \\
+\mathrm{CQ}, 5 \mathrm{mg} / \mathrm{kg}\end{array}$ & $4.6624 \pm 2.72$ & $0.6173 \pm 0.17$ & 13.24 & $0.0859 \pm 0.06^{* *}$ & 1.86 & 90.52 & $5 / 5$ \\
\hline III & $\begin{array}{l}\text { Normal } \\
\text { pellets+ } \\
\text { Extract } \\
100 \mathrm{mg} / \mathrm{kg}\end{array}$ & $4.6328 \pm 1.88$ & $0.6338 \pm 0.29$ & 13.68 & $0.2707 \pm 0.13^{*}$ & 5.84 & 70.23 & $4 / 5$ \\
\hline IV & $\begin{array}{l}\text { Normal } \\
\text { pellets+ } \\
\text { Extract, } \\
200 \mathrm{mg} / \mathrm{kg}\end{array}$ & $4.6951 \pm 1.65$ & $0.6080 \pm 0.25$ & 12.95 & $0.1208 \pm 0.10^{* *}$ & 2.57 & 86.90 & $5 / 5$ \\
\hline
\end{tabular}

$*=\mathrm{p}>0.05$

$* *=\mathrm{p}<0.05$ compared to control.

TABLE 3: CURATIVE PROPERTY OF XYLOPIA PARVIFLORA EXTRACT ON P. YOELL INFECTED MICE FED PALM OIL SUPPLEMENT PELLETS.

\begin{tabular}{|c|c|c|c|c|c|c|c|c|}
\hline GP & $\begin{array}{l}\text { TREATMEN } \\
\mathrm{T}\end{array}$ & $\begin{array}{l}\text { MEAN RBC } \\
\text { BEFORE } \\
\text { INOCULATIO } \\
\mathrm{N}\left(\mathrm{X}_{10}^{6} / \mathrm{MM}^{3}\right)\end{array}$ & $\begin{array}{l}\text { MEAN } \\
\text { PARASITISE } \\
\text { D RBC } 72 \mathrm{hrs} \\
\text { AFTER } \\
\text { INOCULATI } \\
\text { ON } 1 \mathrm{X} \\
\left.10^{6} / \mathrm{MM}^{3}\right)\end{array}$ & $\begin{array}{l}\% \\
\text { PARASI } \\
\text { TAEMIA } \\
\text { 72hrs } \\
\text { AFTER } \\
\text { INOCUL } \\
\text { ATION }\end{array}$ & $\begin{array}{l}\text { MEAN } \\
\text { PARASITISE } \\
\text { D RBC } \\
\text { AFTER 96hrs } \\
\text { OF } \\
\text { TREATMEN } \\
\text { T }\end{array}$ & $\begin{array}{l}\% \\
\text { PARASI } \\
\text { TAEMIA } \\
\text { AFTER } \\
\text { 96hrs OF } \\
\text { TREAT } \\
\text { MENT }\end{array}$ & $\begin{array}{l}\% \\
\text { SUPP } \\
\text { RESS } \\
\text { ION }\end{array}$ & $\begin{array}{l}28- \\
\text { DAY } \\
\text { SURVI } \\
\text { VAL }\end{array}$ \\
\hline I & $\begin{array}{l}\text { Palm oil } \\
\text { supplemented } \\
\text { feed+ Normal } \\
\text { sale } 1 \mathrm{ml} / \mathrm{kg}\end{array}$ & $4.8234 \pm 1.67$ & $0.7828 \pm 0.27$ & 16.23 & $0.9517 \pm 0.27$ & 19.73 & - & $0 / 5$ \\
\hline II & $\begin{array}{l}\text { Palm oil } \\
\text { supplemented } \\
\text { feed+CQ } \\
5 \mathrm{mg} / \mathrm{kg}\end{array}$ & $4.8861 \pm 2.64$ & $0.6983 \pm 0.22$ & 14.29 & $\begin{array}{l}0.2093 \pm \\
0.14 * *\end{array}$ & 4.28 & 78.31 & $5 / 5$ \\
\hline III & $\begin{array}{l}\text { Palm oil } \\
\text { supplemented } \\
\text { feed+ Extract, } \\
100 \mathrm{mg} / \mathrm{kg}\end{array}$ & $4.6119 \pm 1.84$ & $0.6969 \pm 0.28$ & 15.11 & $\begin{array}{ll}0.4852 & \pm \\
0.17 * & \end{array}$ & 10.52 & 46.68 & $1 / 5$ \\
\hline IV & $\begin{array}{l}\text { Palm oil - } \\
\text { supplemented } \\
\text { feed+ Extract, } \\
200 \mathrm{mg} / \mathrm{kg}\end{array}$ & $4.7681 \pm 1.82$ & $0.7918 \pm 0.18$ & 16.61 & $\begin{array}{l}0.3225 \\
0.15^{* * *}\end{array}$ & 6.76 & 65.74 & $5 / 5$ \\
\hline
\end{tabular}

$*=\mathrm{p}>0.05$

$* *=\mathrm{p}<0.05$ compared to control. 
Antiplasmodial Effect of A Crude Extract Of The Leaves of Xylopia Parviflora (Benth) On

TABLE 4: EFFECT OF XYLOPIA PARVIFLORA EXTRACT INFECTED MICE FED PROTEIN DEFICIENT PELLETS

\begin{tabular}{|c|c|c|c|c|c|c|c|c|}
\hline GP & TREATMENT & $\begin{array}{l}\text { MEAN RBC } \\
\text { BEFORE } \\
\text { INOCULATION } \\
\left(\mathrm{X} 10 / \mathrm{MM}^{3}\right)\end{array}$ & $\begin{array}{l}\text { MEAN } \\
\text { PARASITES } \\
\text { RBC } 72 \text { HRS } \\
\text { AFTER } \\
\text { INOCULATION } \\
\left(\mathrm{X} 10^{6} / \mathrm{MM}^{3}\right)\end{array}$ & $\begin{array}{l}\text { \% } \\
\text { PARASITISED } \\
\text { RBC } 72 \mathrm{hrs} \\
\text { AFTER } \\
\text { INOCULATION }\end{array}$ & $\begin{array}{l}\text { MEAN } \\
\text { PARASITISED } \\
\text { RBC AFTER } \\
96 \mathrm{hrs} \text { OF } \\
\text { TREATMENT }\end{array}$ & $\begin{array}{l}\% \\
\% \\
\text { PARASITISED } \\
\text { RBD AFTER } \\
96 \mathrm{hrs} \text { OF } \\
\text { TREATMENT }\end{array}$ & $\begin{array}{l}\% \\
\text { SUPPRESSION }\end{array}$ & $\begin{array}{l}\text { 28-DAY } \\
\text { SURVIVAL }\end{array}$ \\
\hline I & $\begin{array}{l}\text { Protein } \\
\text { deficient } \\
\text { Pellets + } \\
\text { Normal saline } \\
1 \mathrm{ml} / \mathrm{kg}\end{array}$ & $4.1626 \pm 2.69$ & $0.8605 \pm 0.22$ & 20.67 & $0.9816 \pm 0.28$ & 23.58 & - & $0 / 5$ \\
\hline II & $\begin{array}{l}\text { Protein } \\
\text { deficient } \\
\text { Pellets + CQ } \\
5 \mathrm{mg} / \mathrm{kg}\end{array}$ & $4.1533 \pm 1.86$ & $0.7954 \pm 0.28$ & 19.15 & $0.2129 \pm 0.14^{88}$ & 5.13 & 78.24 & $5 / 5$ \\
\hline III & $\begin{array}{l}\text { Protein } \\
\text { deficient } \\
\text { Pellets } \\
+ \text { Extract, } \\
100 \mathrm{mg} / \mathrm{kg}\end{array}$ & $4.1838 \pm 2.81$ & $0.7995 \pm 0.32$ & 19.11 & $0.4603 \pm 0.18^{8}$ & 11.00 & 53.35 & $3 / 5$ \\
\hline IV & $\begin{array}{l}\text { Protein } \\
\text { deficient } \\
\text { Pellets } \\
+ \text { Extract, } \\
200 \mathrm{mg} / \mathrm{kg}\end{array}$ & $4.1173 \pm 1.93$ & $0.7657 \pm 0.17$ & 18.60 & $0.3538 \pm 0.12^{*}$ & 8.59 & 63.57 & $3 / 5$ \\
\hline
\end{tabular}

$*=\mathrm{p}>0.05$

$* *=p<0.05$ compared to control.

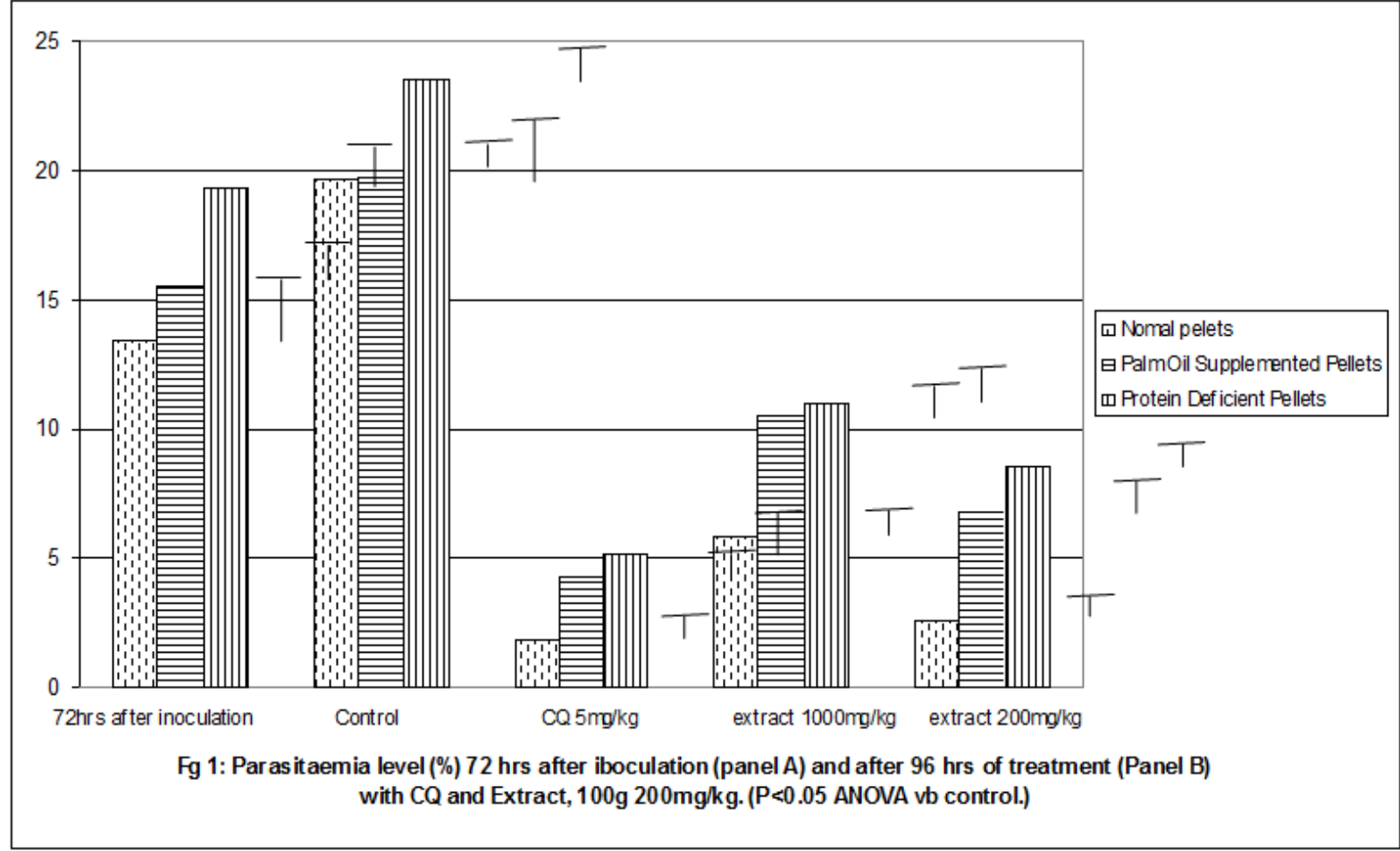




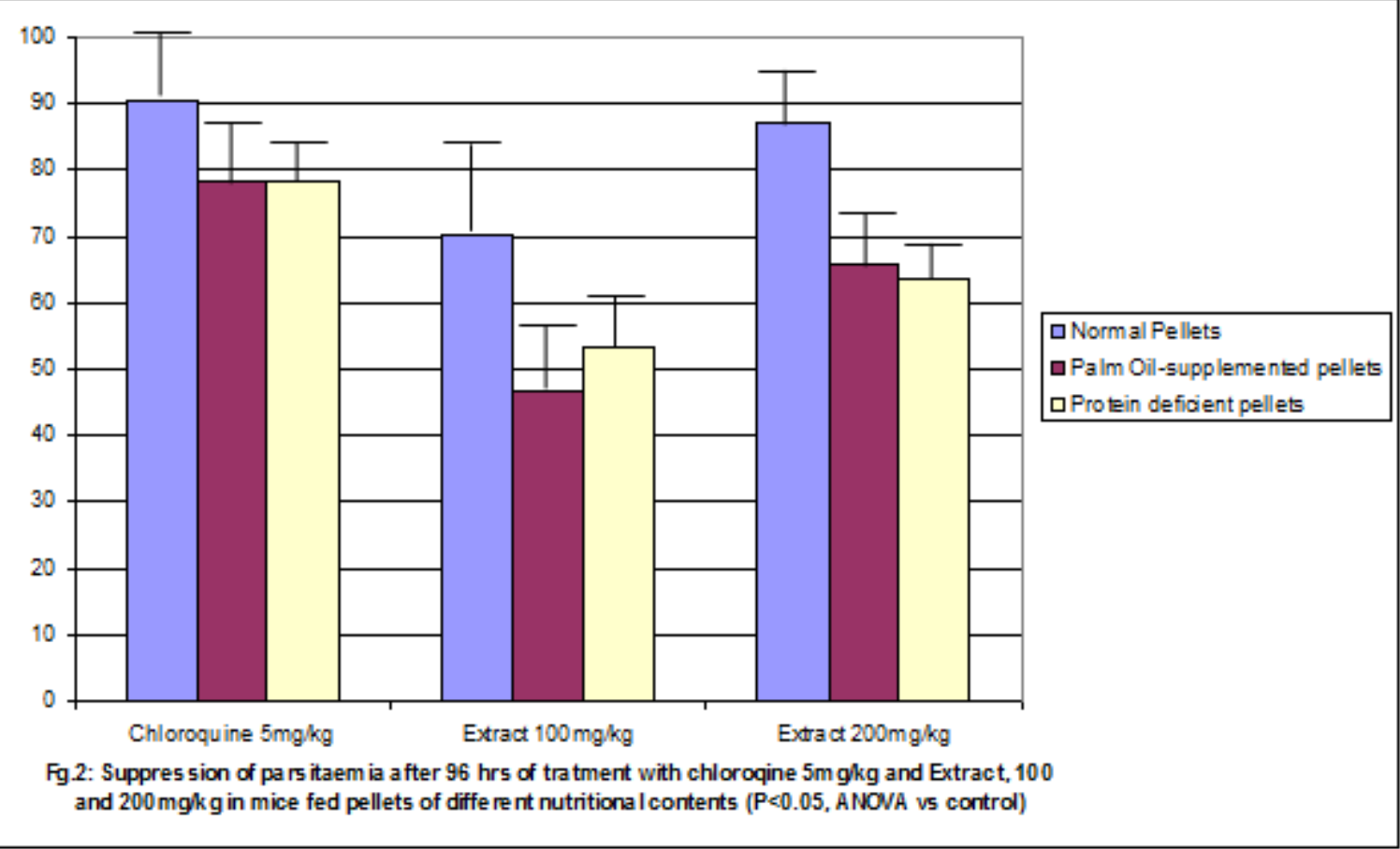

